\title{
Selection of potentially probiotic Kluyveromyces lactis for the fermentation of cheese whey-based beverage
}

\author{
Daelen Resende Oliveira ${ }^{1}$ - Ana Claudia Alencar Lopes ${ }^{1}$. Rafaela Andrade Pereira ${ }^{1}$. \\ Patricia Gomes Cardoso ${ }^{1}$ - Whasley Ferreira Duarte ${ }^{1}$
}

Received: 7 June 2019 / Accepted: 13 September 2019 / Published online: 1 November 2019

(C) Università degli studi di Milano 2019

\begin{abstract}
Purpose This work aimed to assess the probiotic potential of different Kluyveromyces lactis strains isolated from Canastra cheese and to produce a fermented cheese whey beverage added to beetroot juice using the selected strain.

Methods Kluyveromyces lactis strains were tested for their resistance to the passage through the simulated gastrointestinal tract, adhesion properties, and functional effects such as inhibition of enteric pathogens, short-chain fatty acids (SCFA) production, and $\beta$-galactosidase activity. The selected strain was used to produce a fermented cheese whey beverage added to beetroot juice in different proportions. The produced beverages were characterized using HPLC for sugars, Folin-Ciocalteu for total phenolic content, DPPH for antioxidant activity, and GC-MS for volatiles compounds.

Results Except B51, all strains showed viability above $75 \%$ after exposure to the simulated gastric and duodenal juices. The aggregation rates were above $84 \%$ in $24 \mathrm{~h}$. Only B9 and C16 strains presented hydrophobicity above $60 \%$. The highest B9 $\beta$ galactosidase activities were $2.17 \mathrm{U} / \mathrm{g}$ and $2.21 \mathrm{U} / \mathrm{g}$ for $\mathrm{pH} 7$ and 9, respectively. The B9 SCFA profile was similar to that found for Saccharomyces bourllardi. The fermented cheese whey beverages presented phenolic content ranging from 102.75 to $291.61 \mu \mathrm{g} \mathrm{EAG} / \mathrm{mL}$ and inhibition of DPPH ranging from 38.69 to $81.02 \%$ after 21 days of storage, besides being lactose free. Esters and acetates were the most abundant compounds.

Conclusions Kluyveromyces lactis B9 presented interesting results as a potential probiotic yeast. The produced beverages allowed the delivery of $K$. lactis B9 through innovative product with functional properties.
\end{abstract}

Keywords $\beta$-Galactosidase $\cdot$ Functional beverages $\cdot$ Antioxidant activity $\cdot$ Volatile compounds

\section{Introduction}

Probiotics have been increasingly highlighted as a research subject in the last years. They are defined as living microorganisms capable of conferring health benefits to the host when administered in adequate quantities (FAO and WHO 2002). Probiotics exert several benefits to human health, such as helping to maintain intestinal integrity and immunological modulation. Other benefits such as cholesterol reduction, vitamin B production, regularization of intestinal microbiota, and increased bioavailability of nutrients are also associated with probiotics (Cummings and Macfarlane 2002).

Whasley Ferreira Duarte

whasleyduarte@ufla.br

1 Department of Biology, University of Lavras (UFLA), Campus Universitário, Lavras, MG CEP 37.200-000, Brazil
The genera of microorganisms most used as probiotics in the food industry are Lactobacillus and Bifidobacterium, commonly used in dairy products. Alternatively to bacteria, yeasts have been exploited for their probiotic potential. Genera such as Kluyeromyces, Debaromyces, Torulaspora, Pichia, Cryptococcus, Zygosaccharomyces, Trichosporon, and Candida have demonstrated probiotic potential, tolerating passage through the gastrointestinal tract (Chen et al. 2010a, b; Rajkowska and Kunicka-Styczynsk 2010; Hatoum et al. 2012; Syal and Vohra 2013; Diosma et al. 2014; Aloglu et al. 2016; Fadda et al. 2017; Amorim et al. 2018).

Yeasts of the genus Kluyveromyces, mainly Kluyveromyces lactis, have emerged as one of the most important yeast species for research and industrial biotechnology being used for the production of metabolites and proteins, mainly the enzyme $\beta$ galactosidase already commercialized for industrial purposes such as the production of lactose-free dairy products (Spohner et al. 2016). They are frequently isolated from milk and cheese 
and naturally consumed along with these foods (Andrade et al. 2017; Ceugniez et al. 2017; Fadda et al. 2017). This genus has also shown resistance to the passage through the gastrointestinal tract and potential for adhesion to the intestinal epithelium, as well as functional properties such as short-chain fatty acid production, immune modulation, inhibition of pathogens, and pro-apoptotic activity in cancerous epithelial cells (Kumura et al. 2004; Maccaferri et al. 2012; Ceugniez et al. 2017; Saber et al. 2017). These considerations make evident the importance of the search for new yeasts strains, which have the beneficial effects common to established one and/or other beneficial effects. Besides, the discovery of new probiotics yeast would enable the production and marketing of new types of beverages and probiotic foods.

Fermented beverages are used as vehicles for probiotics in the human diet, mainly milk-based beverages. In this context, cheese whey is an interesting raw material for the production of functional foods with probiotics. It is rich in calcium, bioactive peptides, and essential amino acids such as leucine, valine, isoleucine, and cysteine, which are important agents in metabolism, neural function, and homeostasis (Patel 2015). Since the cheese whey concentration process results in a relatively high cost for the industry, the use of non-concentrated cheese whey may represent an interesting alternative for cost reduction. For this reason, we evaluated the use of nonconcentrated cheese whey compared with concentrated cheese in the production of a fermented beverage.

Although dairy beverages are the most frequent beverages used for the delivery of probiotics, the industry has been looking for different probiotic foods that promote health benefits. Besides dairy products, fruits such as pineapple and Cornelian cherry have been recently reported by Costa et al. (2013) and Amorim et al. (2018) as good substrates to produce probiotic beverages. Unlike fruit juices, the vegetable juices are still little explored for the production of probiotic beverages. As vegetables have excellent nutritional properties with a high content of amino acids, vitamins, and the presence of biologically active antioxidant compounds (Kiefer et al. 2004), they are also good substrate to be used in the fermentation with probiotics. One interesting vegetable in this context is beetroot whose juice contains a high level of biologically available antioxidants and many other health-promoting compounds such as potassium, magnesium, folic acid, iron, zinc, calcium, phosphorus, niacin, biotin, and fibers (Wootton-Beard and Ryan 2011). In this work, we used beetroot juice to obtain a fermented beverage added to these health-beneficial components, especially the antioxidant compounds.

The objective of this work was to evaluate the probiotic potential of different $K$. lactis strains previously isolated from Canastra cheese production process and additionally use the selected strain to produce a fermented cheese whey beverage added to beetroot juice.

\section{Materials and methods}

\section{Microorganisms used}

The eleven studied $K$. lactis strains were previously isolated from the Canastra cheese (Andrade et al. 2017) production process. The strain Saccharomyces cerevisiae var. boulardii (S1) was got from the commercial product Floratil® AT 250 (Merck KGaA, Darmstadt, Germany) and used in all experiments as a control.

\section{Inoculum preparation}

The strains were initially grown at $28^{\circ} \mathrm{C}$ for $48 \mathrm{~h}$ in $2 \mathrm{mLYPD}$ broth (1\% yeast extract, $2 \%$ peptone, and $1 \%$ glucose) until reaching the $10^{7} \mathrm{cell} / \mathrm{mL}$. The obtained cultures were centrifuged at $5000 \mathrm{rpm}$ for $10 \mathrm{~min}$ at $4{ }^{\circ} \mathrm{C}$ and then washed with (PB) $(\mathrm{g} / \mathrm{L}$ : sodium chloride 8.0 , potassium chloride 0.2 , disodium phosphate 1.44 , and potassium phosphate 0.24 ; $\mathrm{pH}$ 7). The biomass was used as the initial inoculum for tests described below.

\section{Evaluation of probiotic potential}

\section{Passage through the simulated gastrointestinal tract}

To evaluate the passage through the upper gastrointestinal tract, the cells were initially exposed to $10 \mathrm{~mL}$ of synthetic gastrointestinal juice $(6.2 \mathrm{~g} / \mathrm{L} \mathrm{NaCl}, 2.2 \mathrm{~g} / \mathrm{L} \mathrm{KCl}, 0.22 \mathrm{~g} / \mathrm{L}$ $\mathrm{CaCl}_{2}, 1.2 \mathrm{~g} / \mathrm{L} \mathrm{NaHCO}{ }_{3}, 0.3 \%$ pepsin, $\mathrm{pH} 3.0$ ) and incubated at $37{ }^{\circ} \mathrm{C}$ under stirring. After $90 \mathrm{~min}, 17.5 \mathrm{~mL}$ of synthetic duodenal juice $\left(6.4 \mathrm{~g} / \mathrm{L} \mathrm{NaHCO}_{3}, 0.24 \mathrm{~g} / \mathrm{L} \mathrm{KCl}, 1.28 \mathrm{~g} / \mathrm{L}\right.$ $\mathrm{NaCl}, 0.1 \%$ pancreatin, $4 \mathrm{~mL}$ of bile $10 \%$ ) adjusted to $\mathrm{pH} 7.4$ with $5 \mathrm{M} \mathrm{HCl}$ was added to the $10 \mathrm{~mL}$ synthetic gastrointestinal juice. To determine the strains survival rate, at 0 (T0), 90 (T1), and 270 (T2) min, samples were plated in YPD with incubation at $37^{\circ} \mathrm{C}$ for $48 \mathrm{~h}$ (Fadda et al. 2017).

\section{Auto-aggregation test}

The auto-aggregation test was performed according to Fadda et al. (2017) with modifications. The cell biomass was resuspended in $3 \mathrm{~mL}$ of PBS; the solution was vortexed for $10 \mathrm{~s}$ and then subjected to OD reading in a spectrophotometer at of $560 \mathrm{~nm}$. The solution was kept in the cuvette, incubated at $37^{\circ} \mathrm{C}$ for further readings at times 2,4 , and $24 \mathrm{~h}$. The percentage of auto-aggregation was expressed by the equation:

Auto-aggregation $\%=(\mathrm{At} / \mathrm{A} 0) \times 100$

where At represents the absorbance at time $2 \mathrm{~h}, 4 \mathrm{~h}$, or $24 \mathrm{~h}$, and $A 0$ represents the absorbance at time $0 \mathrm{~h}$. 


\section{Hydrophobicity assay}

The cell biomass was resuspended in $5 \mathrm{~mL}$ PBS and from this, aliquots of $3 \mathrm{~mL}$ were placed in contact with $1 \mathrm{~mL}$ of $\mathrm{n}$ hexadecane and vortexed for $120 \mathrm{~s}$. The solution was incubated for $1 \mathrm{~h}$ at $37^{\circ} \mathrm{C}$ to allow complete separation of phases. The aqueous phase was carefully removed, and the absorbance was measured in a spectrophotometer at $560 \mathrm{~nm}$ (Fadda et al. 2017).

The decrease in absorbance was taken as a measure of the hydrophobicity of the cell surface, calculated using the equation:

\section{$[(\mathrm{OD} 0-\mathrm{OD}) / \mathrm{OD} 0] \times 100$}

where $O D 0$ and $O D$ are the optical densities before and after the contact with n-hexadecane, respectively.

\section{Functional activities}

\section{Activity $\beta$-galactosidase}

The strains pre-selected based on the above-described tests were used for the determination of their $\beta$-galactosidase activity. The inoculum obtained as described previously was transferred to $10 \mathrm{~mL}$ of the enzyme production medium (3.0\% lactose, $0.7 \%$ yeast extract, $0.3 \%$ peptone, $0.1 \%$ $\mathrm{KH}_{2} \mathrm{PO}_{4}, 0.05 \% \quad \mathrm{MgSO}_{4} \cdot 7 \mathrm{H}_{2} \mathrm{O}, 0.3 \% \quad \mathrm{~K}_{2} \mathrm{HPO}_{4}$ ) (Song et al. 2010) and incubated at $30{ }^{\circ} \mathrm{C} / 200 \mathrm{rpm}$ for $48 \mathrm{~h}$. After, $500 \mathrm{mg}$ of biomass was harvested and used for the cell permeabilization with the addition of $5 \mathrm{~mL}$ of isoamyl alcohol, $25 \mathrm{~mL}$ of phosphate buffer, and glass bead (1 mm) followed by vortexing for $5 \mathrm{~min}$ and incubation under stirring for a further $15 \mathrm{~min}$ at room temperature. The substrate for the enzyme was prepared according to Cardoso et al. (2015). Initially, $200 \mu \mathrm{L}$ of permeabilized cell solution was placed in contact with $800 \mu \mathrm{L}$ of the ONPG solution (2.5 $\mathrm{mg} / \mathrm{mL}$ ONPG in $0.1 \mathrm{M}$ phosphate buffer, $\mathrm{pH}$ 6); the reaction occurred for $15 \mathrm{~min}$ at $37^{\circ} \mathrm{C}$ and then was stopped by the addition of $200 \mu \mathrm{L} \mathrm{Na} \mathrm{CO}_{3}(\mathrm{mmol} / \mathrm{L})$. The OD was read in a spectrophotometer at $420 \mathrm{~nm}$. For the calculation of the enzymatic activity, an ONPG extinction coefficient of $4.6 \mathrm{mM}$ was used.

\section{Stability $\beta$-galactosidase}

The strain that showed the best result in the first assay was then submitted to a new test for the characterization of the

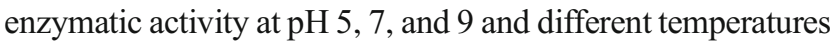
$\left(20{ }^{\circ} \mathrm{C}, 30{ }^{\circ} \mathrm{C}\right.$, and $45^{\circ} \mathrm{C}$ ) in order to verify the $\beta$ galactosidase stability.

\section{Inhibition of pathogens}

Three methods proposed by Ceugniez et al. (2015) were used to evaluate the inhibitory potential against pathogens, with some modifications. In the "late method," $100 \mu \mathrm{L}$ of yeast culture $\left(10^{8}\right.$ cell $\left./ \mathrm{mL}\right)$ was plated in YPD and incubated at $28{ }^{\circ} \mathrm{C}$ for $48 \mathrm{~h}$. The colonies were then removed, and plates were inoculated with $100 \mu \mathrm{L}\left(10^{4}\right.$ cell $\left./ \mathrm{mL}\right)$ of the pathogen cultures (Escherichia coli ATCC 055, Salmonella enteritidis ATCC 5190, and Listeria monocytogenes ATCC 11778). Plates were incubated at $37^{\circ} \mathrm{C}$ for $48 \mathrm{~h}$.

In the "supernatant assay," the TSA plates were flooded with $100 \mu \mathrm{L}$ of the pathogen cultures which were allowed to dry. After, 7 wells of $5 \mathrm{~mm}$ were made on each plate and filled with filtered $(0.22 \mu \mathrm{m})$ yeast growth medium. The plates were incubated for $2 \mathrm{~h}$ at $4{ }^{\circ} \mathrm{C}$ to allow the diffusion of the supernatant and then incubated at $37^{\circ} \mathrm{C}$ for $48 \mathrm{~h}$.

In the "gas production antagonism test," two compartment plates were inoculated with a yeast culture in one compartment and with the pathogen cultures in another compartment. The plates were incubated at $37{ }^{\circ} \mathrm{C}$ for $48 \mathrm{~h}$. For all of these experiments, the presence or absence of zones of inhibition was inspected after the incubation periods.

\section{Fermentation of prebiotic and production of short-chain fatty acids}

To evaluate the capacity of selected strain to ferment prebiotic fibers and produce short-chain fatty acids (SCFA), a fermentation was performed using a medium composed by peptone (2\%), yeast extract (1\%), and as a source of carbon, $2 \%$ of commercial prebiotic Tamarine fibers ${ }^{\circledR}$ (inulin, fructooligosaccharide, and polydextrose). The fermentation was carried out at $37{ }^{\circ} \mathrm{C}$ in anaerobiosis and samples were withdrawn at $6 \mathrm{~h}, 12 \mathrm{~h}$, and 24 h. A control fermentation was inoculated with a commercial probiotic mix (Probiatop®) containing the Lactobacillus paracasei, Lactobacillus rhamnosus, Lactobacillus acidophilus, and Bifidobacterium lactis. This bacterial mix was chosen as a "control" treatment due to the recognized efficiency of bacteria to produce high concentrations of SCFA. The collected samples were analyzed by gas chromatography using a GC-FID (Shimadzu) equipped with a BP21 column $(30 \mathrm{~m} \times$ $0.25 \mathrm{~mm} \times 0.25 \mu \mathrm{m})$. The injector and detector were kept at $180{ }^{\circ} \mathrm{C}$ and $200{ }^{\circ} \mathrm{C}$, respectively. The oven was maintained at $200{ }^{\circ} \mathrm{C}$ and the carrier gas flow was $1.1 \mathrm{~mL} / \mathrm{min}$. Butyric, acetic, and propionic acids were identified by comparison of their retention time with the retention times of pure standard. The quantification was performed using external calibration curves. 


\section{Elaboration of fermented beverages}

\section{Inoculum preparation}

The selected strain was reactivated in $2 \mathrm{~mL}$ YPD and incubated at $28^{\circ} \mathrm{C}$ for $24 \mathrm{~h}$. Afterward, the biomass was transferred to Erlenmeyer flasks containing $100 \mathrm{~mL}$ of medium, incubated for $48 \mathrm{~h}$ followed by the subsequent transfer of the biomass to $1 \mathrm{~L}$ of YPD, which was incubated until the population reached $10^{8}$ cells $/ \mathrm{mL}$.

\section{Preparation of raw material}

The cheese whey concentration by nanofiltration was performed in a dairy factory in Lavras-MG. The non-concentrated cheese whey was collected right after the cheese mass separation in the production process at the dairy pilot plant of the Food Science Department at the University of Lavras. The beetroot juice was prepared by grinding the vegetable with water in the ratio $1: 1$ $(w: v)$. The cheese whey and beetroot juice were pasteurized using direct steam in an autoclave for $7 \mathrm{~min}$ (Andrade et al. 2017).

\section{Fermentation and addition of beetroot juice}

The pasteurized concentrated (CW) and non-concentrated (NW) cheese whey were inoculated with $10^{8}$ cells $/ \mathrm{mL}$ of potential probiotic $K$. lactis strain followed by incubation at $28^{\circ} \mathrm{C}$ until $120 \mathrm{~h}$ after the stabilization of Brix. After fermentation, the beetroot juice was added to the fermented cheese whey in the ratios of 1:1 and 1:3 (fermented cheese whey:beetroot juice).

\section{Stability of beverages}

The produced beverages were bottled in $250-\mathrm{mL}$ clear bottles, which were kept under refrigeration at $4{ }^{\circ} \mathrm{C}$ for 21 days. Every 7 days, a bottle was opened for yeast, psychotropic and mesophilic bacteria counting. Aliquots of the beverages were plated in Plate Count Agar (PCA) (yeast extract 0.25\%, peptone $0.5 \%$, glucose $0.1 \%$, agar $1.5 \%$ ), supplemented with nystatin $0.4 \mathrm{~g} / \mathrm{L}$, and the plates were incubated at $37{ }^{\circ} \mathrm{C}$ for mesophilic bacteria and $4{ }^{\circ} \mathrm{C}$ for psychotropic bacteria. The yeast viability was determined using YPD agar with $1 \mathrm{~g} / \mathrm{L}$ chloramphenicol followed by incubation at $28^{\circ} \mathrm{C}$ for $48 \mathrm{~h}$.

\section{Analysis of sugars by HPLC}

The main sugars in the 21 days beverages were analyzed by HPLC which was performed using a Shimadzu chromatograph equipped with a refractive index detector (RID-10A) and Supelcogel $8 \mathrm{H}$ column operated at $30^{\circ} \mathrm{C}$. Elution was performed with $5 \mathrm{mM}$ sulfuric acid at a flow rate of $0.4 \mathrm{~mL} /$ min. The compound identification was performed by comparing the retention times of the peaks in the samples with those of the pure standards injected under the same conditions. The quantification was performed using the external calibration method (Duarte et al. 2010; Andrade et al. 2017).

\section{Quantification of total phenolics}

The total content of polyphenols was determined using the method of Folin-Ciocalteu, according to Wootton-Beard and Ryan (2011) with adaptations. A 0.2-mL aliquot of each beverage was added to $1.5 \mathrm{~mL}$ of Folin-Ciocalteu reagent $(1: 10 \mathrm{v} /$ v). The solution was allowed to equilibrate for $5 \mathrm{~min}$ and then mixed with $1.5 \mathrm{~m} / \mathrm{L}$ of sodium carbonate $(60 \mathrm{~g} / \mathrm{L})$, followed by incubation in the dark for $90 \mathrm{~min}$. The absorbance of the mixture was read at $725 \mathrm{~nm}$ using the respective solvent as blank. The results were expressed in milligram equivalents of gallic acid.

\section{Evaluation of the antioxidant activity of the beverages}

The method of Escudero-López et al. (2016) was used with modifications. First, $120 \mu \mathrm{L}$ of the centrifuged beverages $\left(10,000 \mathrm{rpm}, 10 \mathrm{~min}, 4{ }^{\circ} \mathrm{C}\right)$ and $600 \mu \mathrm{L}$ of methanol were mixed. Then, $180 \mu \mathrm{L}$ of a DPPH solution $(0.5 \mathrm{mM}$ in ethanol $)$ was added. The reaction was incubated for $60 \mathrm{~min}$ at $30^{\circ} \mathrm{C}$ in the dark and after that, read in a spectrophotometer at $517 \mathrm{~nm}$. Ethanol was used as blank and the DPPH solution without juice addition, the control. The percentage of DPPH reduction was calculated as follows:

[(Control Absorbance - Sample Absorbance)/Control Absorbance*100]

\section{Analysis of volatile compounds by HS SPME GC-MS}

The volatile compounds were extracted from the headspace using $5 \mathrm{~mL}$ of sample loaded in $15 \mathrm{~mL}$ vials. The extraction was carried out at $60{ }^{\circ} \mathrm{C}$ for 25 min with a DVB/Carboxen/PDMS Stable flex SPME (Supelco, Bellefonte, PA, USA) fiber in a manual holder (Andrade et al. 2017). The extracted compounds were analyzed in a GC-MS-QP2010 Plus (Shimadzu) chromatograph equipped with a Rts-5MS $(30 \mathrm{~m} \times 0.25 \mathrm{~mm} \times 0.25 \mu \mathrm{m})$ column. Thermal desorption was at $270{ }^{\circ} \mathrm{C}$ for $100 \mathrm{~s}$ and injections in splitless mode ( $30 \mathrm{~s}$ at $25 \mathrm{psi})$. The system was operated at $35{ }^{\circ} \mathrm{C}$ and increment of $4{ }^{\circ} \mathrm{C} / \mathrm{min}$ until reaching $240{ }^{\circ} \mathrm{C}$ using helium at $1.78 \mathrm{~mL} / \mathrm{min}$ as the carrier gas. Compounds were identified using the NIST library 2011 and the quantification performed using internal calibration with 4-nonanol at a final concentration of $125 \mu \mathrm{g} / \mathrm{L}$ (Duarte et al. 2010). 


\section{Statistical analysis}

The Sisvar 5.6 software (Lavras-MG) and XLstat 2014.5 software (Addinsoft's, New York, NY) were respectively used for Scott-Knott and principal component analysis. All experiments were performed in triplicate.

\section{Results and discussion}

\section{Probiotic potential}

To exert their functional effect on the human organism, probiotics must first survive to the adversities encountered during the traversal of the gastrointestinal tract. In our work, all the tested $K$. lactis strains showed resistance above $82 \%$ after $90 \mathrm{~min}$ of exposure to simulated gastric juice. The best (Scott-Knott $p<0.05$ ) survival rate of $93.86 \%$ was found for C3 strain (Table 1). These survival rates showed the potential of the studied strains, once the resistance to gastric juice (stomach $\mathrm{pH}$ ) is the first barrier faced by the microorganisms. The hydrochloric acid excreted by the parietal cells is responsible for the acidity in the organism (which $\mathrm{pH}$ ranges from 1.5 to 3.5 ) and acts as a defense against pathogenic microorganism. To be considered probiotic, a bacterium must survive to $\mathrm{pH} 2.0$ and 3.0 during $3 \mathrm{~h}$ (Park et al. 2006). This is also a requirement for probiotic yeasts candidates. The tested $K$. lactis strains were isolated from samples of milk, Canastra cheese, cheese whey, and "pingo" (endogenous starter), which are naturally low $\mathrm{pH}$ environments, a condition that may have favored the resistance of the yeasts to the acidity of the stomach.

Table 1 Resistance of yeast strains in simulated gastric $(90 \mathrm{~min})$ and intestinal (270 $\mathrm{min})$ conditions

\begin{tabular}{lll}
\hline Yeast & Survival rate $(\%) 90 \mathrm{~min}$ & Survival rate $(\%) 270 \mathrm{~min}$ \\
\hline B7 & $88.00 \pm 0.05^{\mathrm{i}}$ & $79.46 \pm 0.02^{\mathrm{h}}$ \\
B9 & $84.09 \pm 0.04^{\mathrm{d}}$ & $83.87 \pm 0.03^{\mathrm{k}}$ \\
B34 & $82.95 \pm 0.11^{\mathrm{b}}$ & $75.31 \pm 0.05^{\mathrm{a}}$ \\
B35 & $86.51 \pm 0.16^{\mathrm{h}}$ & $78.53 \pm 0.00^{\mathrm{e}}$ \\
B51 & $83.27 \pm 0.10^{\mathrm{c}}$ & $75.64 \pm 0.03^{\mathrm{c}}$ \\
C1 & $85.54 \pm 0.15^{\mathrm{e}}$ & $75.99 \pm 0.05^{\mathrm{d}}$ \\
C3 & $93.86 \pm 0.01^{1}$ & $84.03 \pm 0.05^{1}$ \\
C5 & $86.32 \pm 0.01^{\mathrm{g}}$ & $78.61 \pm 0.01^{\mathrm{f}}$ \\
C16 & $85.64 \pm 0.03^{\mathrm{f}}$ & $80.40 \pm 0.01^{\mathrm{i}}$ \\
D19 & $88.35 \pm 0.01^{\mathrm{k}}$ & $81.93 \pm 0.03^{\mathrm{j}}$ \\
D22 & $82.12 \pm 0.03^{\mathrm{a}}$ & $75.43 \pm 0.20^{\mathrm{b}}$ \\
S. boulardii & $88.13 \pm 0.07^{\mathrm{j}}$ & $79.29 \pm 0.06^{\mathrm{g}}$ \\
\hline
\end{tabular}

Averages followed by the same letter did not differ statistically by ScottKnott test $(p>0.05)$
After passing through the simulated gastric juice, the strains were submitted to the pancreatic juice. The pancreatic secretion contains multiple enzymes to digest all three major food groups (proteins, carbohydrates, and fats) (Guyton and Hall 2011). In our work, this pancreatic scenario was experimentally simulated by the addition of commercial pancreatin $\left(\right.$ Creon $\left.{ }^{\circledR}\right)$ to the synthetic duodenal juice which contains the lipase, amylase, and protease. After exposure to simulated pancreatic juice $(270 \mathrm{~min})$, the survival of the strains ranged from $75.31 \%$ (strain B34) to $84.03 \%$ (strain C3). The probiotic Saccharomyces boulardii showed a survival rate of $79.29 \%$, while six (B9, C3, C5, C16, D19, B7) of the tested strains showed higher (Scott-Knott $p<0.05$ ) values (Table 1 ). It is interesting to note that the decrease in the survival rate did not exceed the values previously reported by Ceugniez et al. (2017) and Fadda et al. (2017) for Kluyveromyces strains.

The tolerance to bile salts is an important requirement for probiotic to settle in the intestinal epithelium. The physiological concentration of bile salts in the small intestine ranges from 0.2 to $2.0 \%$. As the bile concentration used in our work was higher than the cited ones found naturally, it is possible to infer that the studied $K$. lactis strains are resistant to bile salts.

After resisting the adversities during the crossing of the upper gastrointestinal tract, the probiotics must be able to adhere to the cells of the intestinal mucosa, once this adhesion prevents their immediate elimination through peristaltic movements (Kos et al. 2003). The studied strains showed auto-aggregation rates ranging from $55.24 \%$ (D19) to $80.58 \%$ (C16) at $4 \mathrm{~h}$, and from $77.14 \%$ (D19) to $94.87 \%$ (C16) at $24 \mathrm{~h}$. The values presented by $\mathrm{C} 16$ strain were statically higher than those found for S. boulardii (Table 2). Only

Table 2 Auto-aggregation of $K$. lactis strains after $0 \mathrm{~h}, 4 \mathrm{~h}$, and $24 \mathrm{~h}$ incubation

\begin{tabular}{llll}
\hline Strains & \multicolumn{3}{l}{ Auto-aggregation $(\%)$} \\
\cline { 2 - 4 } & $0 \mathrm{~h}$ & $4 \mathrm{~h}$ & $24 \mathrm{~h}$ \\
\hline B7 & $32.31 \pm 0.02^{\mathrm{e}}$ & $63.97 \pm 0.01^{\mathrm{h}}$ & $93.67 \pm 0.01^{\mathrm{j}}$ \\
B9 & $35.97 \pm 0.03^{\mathrm{g}}$ & $66.19 \pm 0.13^{\mathrm{j}}$ & $89.93 \pm 0.00^{\mathrm{g}}$ \\
B34 & $25.77 \pm 0.02^{\mathrm{b}}$ & $58.53 \pm 0.00^{\mathrm{d}}$ & $87.37 \pm 0.00^{\mathrm{f}}$ \\
B35 & $49.86 \pm 0.01^{\mathrm{k}}$ & $68.22 \pm 0.01^{\mathrm{k}}$ & $84.79 \pm 0.02^{\mathrm{d}}$ \\
B51 & $16.90 \pm 0.02^{\mathrm{a}}$ & $45.07 \pm 0.01^{\mathrm{a}}$ & $34.51 \pm 0.02^{\mathrm{a}}$ \\
C1 & $47.87 \pm 0.01^{\mathrm{j}}$ & $64.45 \pm 0.01^{\mathrm{i}}$ & $84.83 \pm 0.01^{\mathrm{e}}$ \\
C3 & $29.82 \pm 0.01^{\mathrm{d}}$ & $63.82 \pm 0.00^{\mathrm{f}}$ & $92.98 \pm 0.01^{\mathrm{i}}$ \\
C5 & $37.77 \pm 0.01^{\mathrm{i}}$ & $57.08 \pm 0.01^{\mathrm{c}}$ & $83.26 \pm 0.01^{\mathrm{c}}$ \\
C16 & $67.41 \pm 0.01^{1}$ & $80.58 \pm 0.00^{1}$ & $94.87 \pm 0.00^{1}$ \\
D19 & $36.43 \pm 0.01^{\mathrm{h}}$ & $55.24 \pm 0.01^{\mathrm{b}}$ & $77.14 \pm 0.00^{\mathrm{b}}$ \\
D22 & $32.82 \pm 0.01^{\mathrm{f}}$ & $62.75 \pm 0.01^{\mathrm{e}}$ & $91.30 \pm 0.00^{\mathrm{h}}$ \\
S. boulardii & $27.6 \pm 0.01^{\mathrm{c}}$ & $63.97 \pm 0.01^{\mathrm{g}}$ & $94.85 \pm 0.04^{\mathrm{k}}$ \\
& &
\end{tabular}

Averages followed by the same letter did not differ statistically by ScottKnott test $(p>0.05)$ 
B51 strain presented unsatisfactory results with $34.51 \%$ of auto-aggregation in $24 \mathrm{~h}$ (Table 2). The lowest values of hydrophobicity were found for B35, B51, C1, and S. boulardii. Kluyveromyces lactis strains B9 and C16 presented hydrophobicity rates of $65.80 \%$ and $62.48 \%$, respectively (Fig. 1). Inferences on the adhesion capacity of probiotics to intestinal mucosa have been made based on auto-aggregation and hydrophobicity data (in vitro tests). Recently, Ceugniez et al. (2017) and Fadda et al. (2017) showed the probiotic potential of Kluyveromyces strain evaluating, among others, autoaggregation and hydrophobicity parameters. Here, the data for these two parameters evidenced the potential adhesion of the studied strains to the intestinal mucosa.

\section{Functional activities}

The studied $K$. lactis strains showed no inhibitory activity against the pathogenic bacteria used in this work. However, in this specific case, this result cannot be extrapolated to in vivo conditions considering the complexity of factors that inhibit pathogens or their pathogenicity factors such as competition for the same receptors and nutrients and other actions such as the inhibition of toxins, which could not be evaluated through the used tests. Among the main antagonistic mechanisms exerted by yeast are competition for nutrients, production of killer toxins, $\mathrm{pH}$ changes, and production of compounds (volatile or non-volatile) as organic acids.

Based on statistical differences (Scott-Knott $p<0.05$ ) found for survival rates after the passage through the simulated gastrointestinal tract (270 $\mathrm{min}$ ), auto-aggregation (4 h), and hydrophobicity, the strains coded as B9, C3, and C16 were pre-selected and submitted to a preliminary test for determination of $\beta$-galactosidase activity. The enzymatic activity found was $1.08 \pm 0.22,0.80 \pm 0.10$, and $0.96 \pm 0.13 \mathrm{U} / \mathrm{g}$ for strains B9, C3, and C16 respectively. The enzymatic activity of yeast B9 was statistically superior (Scott-Knott $p<0.05)$ to the activities found for the other 2 yeasts. Kluyveromyces lactis B9 strain was then selected for the enzyme stability test under different conditions. There were no significant differences between the three used temperatures $(p>0.05)$. The general averages for the $\mathrm{pH} 3$ and each temperature, 20, 30, and $45^{\circ} \mathrm{C}$, were respectively $1.76,1.70$, and $1.63 \mathrm{U} / \mathrm{g}$, while the averages of each $\mathrm{pH}$ were $0.71(\mathrm{pH} 5), 2.19(\mathrm{pH} 7)$, and $2.2 \mathrm{U} / \mathrm{g}$ ( $\mathrm{pH}$ 9) (Fig. 2). There was no statistical difference $(p>0.05)$ between the last two values. Therefore, the $\beta$ galactosidase produced by strain B9 has optimum activity at neutral and alkaline $\mathrm{pH}$. The results are interesting from the functional point of view, showing that there is enzyme activity in body temperature and intestinal $\mathrm{pH}$, a possible positive effect that may help in the cases of lactose intolerance. The lactose hydrolysis by microorganisms is important considering the benefit in cases of lactose intolerance, whether by the production of $\beta$-galactosidase in the intestinal lumen or by the use of microorganism to manufacture free-lactose dairy foods.

Besides $\beta$-galactosidase activity, $K$. lactis B9 also showed functional properties through the production of SCFA. Table 3 shows the SCFA (acetate, butyrate, and propionate) produced during the fermentation of commercial prebiotic mix containing inulin, polydextrose, and FOS. Prebiotics are selectively fermented allowing specific modifications in the composition and/or activity of the intestinal microbiota, thus conferring benefits to host health (Gibson et al. 2004). These benefits are derived from the production of metabolic products, especially short-chain fatty acids acetate, propionate, and butyrate. The SCFA profile of $K$. lactis B9 and $S$. bourllardi were similar for the three different times of fermentation, except in the case of acetate (Table 3 ). However, the commercial mix of probiotic bacteria containing L. paracasei, L. rhamnosus, L. acidophilus, and $B$. lactis produced higher (Scott-Knott $p<0.05$ ) concentrations of acetate, reaching $310.81 \mathrm{mmol} / \mathrm{L}$ at the end of $24 \mathrm{~h}$. This concentration is higher than that reported in the intestinal lumen which is around $69.1 \mathrm{mmol} / \mathrm{L}$ in the cecum (Cummings et al. 1987). Although the acetate production by B9 strain was lower than that produced by the bacteria, it was similar to that produced by $S$. boulardii and reported in studies using, for example, the fecal microbiota fermenting FOS, inulin, and
Fig. 1 Hydrophobicity of eleven different $K$. lactis strains. S1, Saccharomyces boulardii

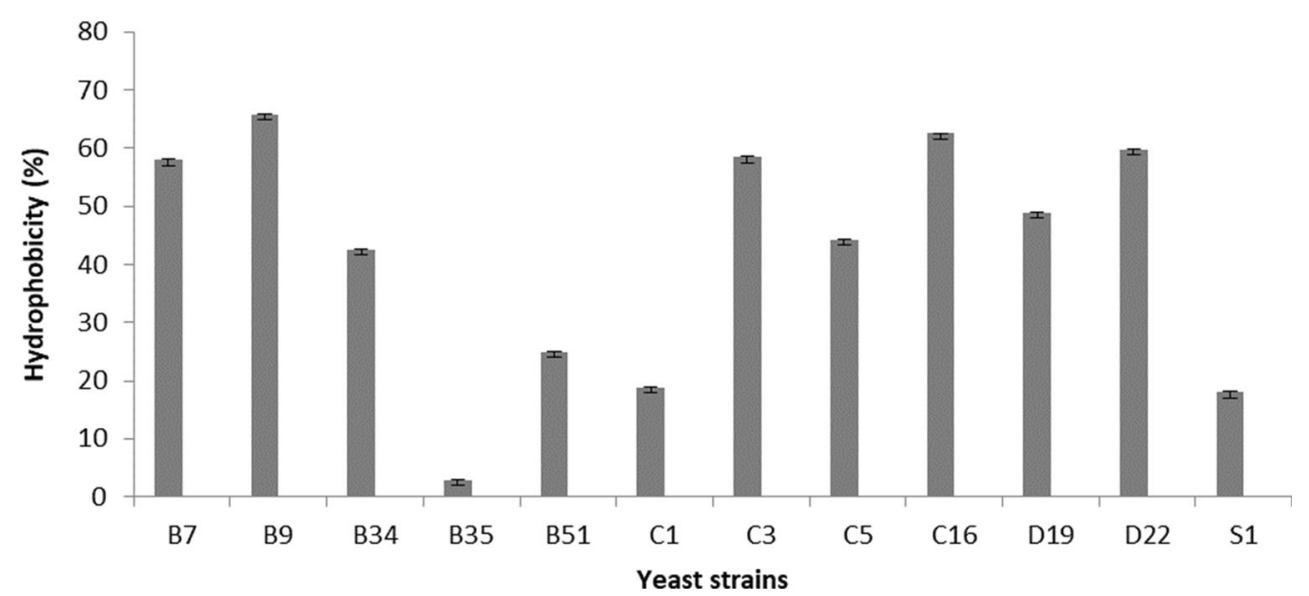




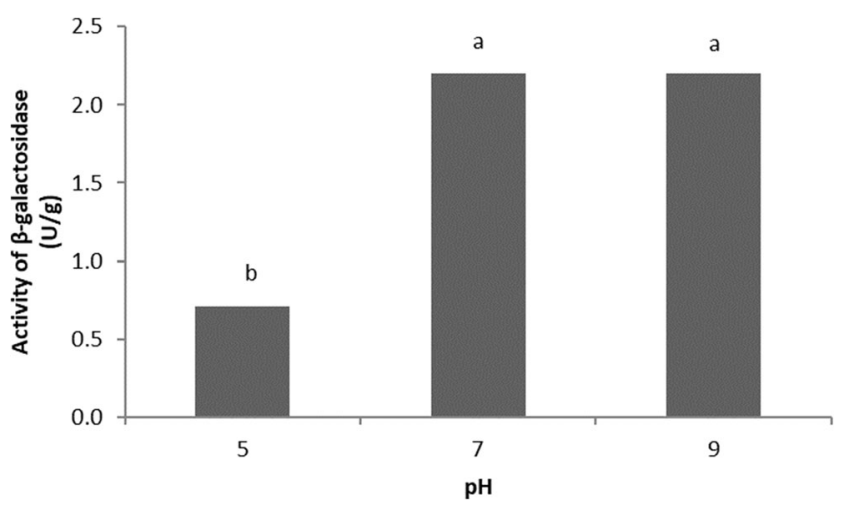

Fig. 2 The $\beta$-galactosidase activity of selected $K$. lactis (B9) at different $\mathrm{pH}$. $\beta$-Galactosidase activities presented as averages of three different temperatures $\left(20,30\right.$, and $\left.45{ }^{\circ} \mathrm{C}\right)$. Different letters indicate statistical difference by Scott-Knott test $(p<0.05)$

polydextrose (Mäkeläinen et al. 2007; Beards et al. 2010; Chen et al. 2018; Di et al. 2018). The SCFAs play a crucial role in health as energy source; for example, butyrate is the main energy source used by the colonocytes. In addition, SCFAs have an immunoregulatory effect, with beneficial effects on inflammatory diseases of the intestinal tract and some forms of cancer. They also influence the metabolism of lipids such as cholesterol, contributing to metabolic conditions that promote preservation or recovery of the endothelial functions and reduce the risk of developing or worsening cardiovascular diseases (Richards et al. 2016). Such benefits show that SCFA is an important parameter for the functional effect of strains with probiotic potential, satisfactorily met by $\mathrm{B} 9$ strain.

Table 3 Concentrations of SCFA at different fermentation time

\begin{tabular}{lllll}
\hline & Time (h) & \multicolumn{2}{l}{ Concentrations of SCFA $(\mathrm{mmol} / \mathrm{L})$} \\
\cline { 3 - 5 } & & K. lactis B9 & Bacteria* & S. boullardi \\
\hline Acetate & 0 & nd & nd & nd \\
& 6 & $8.84 \pm 2.25^{\mathrm{a}}$ & $98.47 \pm 25.29^{\mathrm{b}}$ & $7.87 \pm 1.02^{\mathrm{a}}$ \\
& 12 & $8.24 \pm 0.48^{\mathrm{a}}$ & $134.66 \pm 38.24^{\mathrm{b}}$ & $4.60 \pm 1.80^{\mathrm{a}}$ \\
& 24 & $8.76 \pm 0.32^{\mathrm{a}}$ & $310.81 \pm 77.65^{\mathrm{b}}$ & $3.75 \pm 0.71^{\mathrm{a}}$ \\
Butyrate & 0 & nd & nd & nd \\
& 6 & $0.11 \pm 0.05^{\mathrm{a}}$ & $0.06 \pm 0.01^{\mathrm{a}}$ & $0.16 \pm 0.08^{\mathrm{a}}$ \\
& 12 & $0.13 \pm 0.04^{\mathrm{a}}$ & $0.10 \pm 0.03^{\mathrm{a}}$ & $0.15 \pm 0.02^{\mathrm{a}}$ \\
& 24 & $0.13 \pm 0.01^{\mathrm{a}}$ & $0.25 \pm 0.04^{\mathrm{a}}$ & $0.15 \pm 0.09^{\mathrm{a}}$ \\
Propionate & 0 & $\mathrm{nd}$ & $\mathrm{nd}$ & $\mathrm{nd}$ \\
& 6 & $0.21 \pm 0.12^{\mathrm{a}}$ & $0.11 \pm 0.01^{\mathrm{a}}$ & $0.20 \pm 0.18^{\mathrm{a}}$ \\
& 12 & $0.25 \pm 0.09^{\mathrm{a}}$ & $0.24 \pm 0.04^{\mathrm{a}}$ & $0.21 \pm 0.02^{\mathrm{a}}$ \\
& 24 & $0.26 \pm 0.10^{\mathrm{a}}$ & $0.52 \pm 0.04^{\mathrm{a}}$ & $0.30 \pm 0.29^{\mathrm{a}}$ \\
\hline
\end{tabular}

*Bacteria = probiotic mix: Lactobacillus paracasei, L. rhamnosus, L. acidophilus, and Bifidobacterium lactis

nd $=$ not detected. Averages followed by the same letter did not differ statistically by Scott-Knott test $(p>0.05)$
Characterization of produced beverages

\section{Yeast population}

The $K$. lactis $\mathrm{B} 9$ was selected for the fermentation of concentrated and non-concentrated cheese whey due to its good performance, presenting resistance, adhesion capacity, and high production of $\beta$-galactosidase. Non-concentrated (NW) and concentrated $(\mathrm{CW})$ cheese whey were fermented for $120 \mathrm{~h}$ and after that added to beetroot juice in proportions of $1: 1$ or 1:3 (fermented cheese whey:beetroot juice). The fermentation process started with $1.5 \times 10^{8}$ cells $/ \mathrm{mL}$ and this population remained stable $\left(7.9 \times 10^{8}\right.$ cells $\left./ \mathrm{mL}\right)$ during the shelf life test up to 21 days. To exert beneficial effects, probiotic microorganisms must be alive and available in populations around $10^{8}$ to $10^{9}$ cells $/ \mathrm{g}(\mathrm{mL})$ of the product at the time of consumption. In Brazil, the National Agency of Sanitary Surveillance (ANVISA) recommends that probiotic cell count should be between $10^{8}$ to $10^{9} \mathrm{CFU}$ in the ready-to-eat product, although lower values can be accepted since the effectiveness has been proven. Considering that $\mathrm{B} 9$ strain population remained viable throughout the process, we can infer it could exert its probiotic effects when conveyed via the produced beverage. The produced beverages did not present growth of psychrotrophic and mesophilic bacteria during the 21 days of storage under refrigeration.

\section{Sugars}

The sugar content of cheese whey, beetroot juice, and produced beverages was measured by HPLC (Table 4). In both cases of diluted (NW) and concentrated (CW) cheese whey, at the end of fermentation, yeast completely consumed the sugar content (Table 4), highlighting the efficient activity of $\beta$-galactosidase produced by $K$. lactis B9. This result is in line with the current scenario of the $\beta$-galactosidase use, commonly applied in the food industry to reduce the lactose content of dairy products, preventing problems of crystallization of lactose and increasing sweetness, taste, and solubility (Gänzle et al. 2008). In addition, the hydrolysis of lactose allows the production of lactose-free products suitable for people intolerant to lactose. In general, the sugar profiles of the produced beverages were qualitatively similar, being fructose, glucose, and sucrose the main residual sugars. The most significant (Scott-Knott $p<0.05$ ) difference was the residual fructose content of beverages produced with nonconcentrated cheese whey (NW), which was twice as high as the content of the concentrated cheese whey beverages (CW) (Table 4). This higher fructose content can impact the taste of the beverages since this sugar has a sweetness 2 times greater than, for example, glucose. 
Table 4 Sugar concentration in non-concentrated and concentrated cheese whey, beetroot juice, and fermented beverages

\begin{tabular}{|c|c|c|c|c|c|}
\hline Raw material & Lactose & Fructose & Glucose & Sucrose & Galactose \\
\hline Sweet beet juice & nd & $12.00 \pm 2.12$ & nd & $17.87 \pm 0.18$ & nd \\
\hline Concentrated cheese whey & $55.45 \pm 4.11$ & nd & $58.08 \pm 2.67$ & nd & $38.89 \pm 1.87$ \\
\hline Non-concentrated cheese whey & $46.33 \pm 2.05$ & nd & nd & nd & nd \\
\hline Fermented beverages after 21 days under refrigeration & Lactose & Fructose & Glucose & Sucrose & Galactose \\
\hline Beverage NW 1:1 & nd & $1.50 \pm 0.10^{\mathrm{d}}$ & $2.28 \pm 0.30^{\mathrm{d}}$ & nd & nd \\
\hline Beverage NW 1:3 & nd & $1.63 \pm 0.03^{\mathrm{c}}$ & $1.02 \pm 0.13^{\mathrm{a}}$ & $1.06 \pm 0.50^{\mathrm{b}}$ & nd \\
\hline Beverage CW 1:1 & nd & $0.87 \pm 0.12^{\mathrm{b}}$ & $1.28 \pm 0.10^{\mathrm{b}}$ & $1.29 \pm 0.16^{\mathrm{c}}$ & nd \\
\hline Beverage CW 1:3 & nd & $0.70 \pm 0.17^{\mathrm{a}}$ & $1.90 \pm 0.92^{\mathrm{c}}$ & $0.54 \pm 0.01^{\mathrm{a}}$ & nd \\
\hline
\end{tabular}

NW 1:1, non-concentrated fermented cheese whey added to beetroot juice in a ratio of 1:1 (v:v); NW 1:3 (v:v), non-concentrated fermented cheese whey added to beetroot juice in the ratio of 1:3 (v:v); CW 1:1, concentrated fermented cheese whey added to beetroot juice in the ratio of 1:1 (v:v); CW 1:3, concentrated fermented cheese whey added to beetroot juice in the ratio of $1: 3(\mathrm{v}: \mathrm{v})$. nd, not detected

\section{Total phenolics and antioxidant activity}

Total phenolics (Folin-Ciocalteu) and antioxidant activity (DPPH) were determined at 0 and 21 days of beverages storage under refrigeration at $4{ }^{\circ} \mathrm{C}$. The total phenolic content for all beverages decreased between days 0 and 21 days (Fig. 3). Beverages produced with three parts of beetroot juice presented higher (Scott-Knott $p<0.05$ ) amounts of total phenolics than the beverages produced with one part of juice (Fig. 3). Similar to that observed for total phenolic content, there was also a decrease in the antioxidant activity between the initial and final days of shelf life. The use of three parts of beetroot juice resulted in beverages with higher antioxidant activity (Scott-Knott $p<0.05$ ) than those activities found for the beverages produced with one part of juice beetroot juice (Fig. 4). These reduction profiles were also

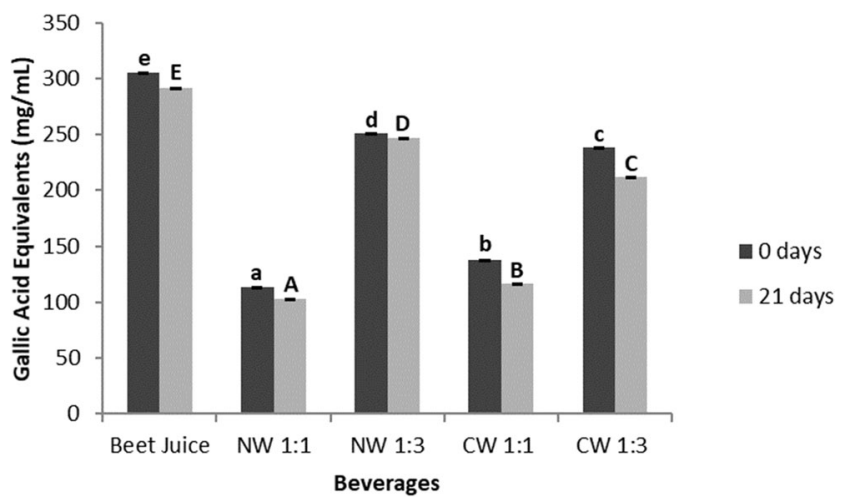

Fig. 3 Total phenolic content of produced beverages at 0 and 21 days of storage under refrigeration at $4{ }^{\circ} \mathrm{C}$. NW $1: 1$, non-concentrated fermented cheese whey added to beetroot juice in a ratio of 1:1 (v:v); NW 1:3 (v:v), non-concentrated fermented cheese whey added to beetroot juice in the ratio of 1:3 (v:v); CW 1:1, concentrated fermented cheese whey added to beetroot juice in the ratio of $1: 1(\mathrm{v}: \mathrm{v})$; CW 1:3, concentrated fermented cheese whey added to beetroot juice in the ratio of $1: 3(\mathrm{v}: \mathrm{v})$. Different capital letters indicate statistical difference (Scott-Knott test $p<0.05$ ) between the beverages at 21 days of storage. Different lowercase letters indicate statistical difference (Scott-Knott test $p<0.05$ ) between the beverages at 0 days of storage observed in the beetroot juice used as control (Figs. 3 and 4). In both cases of total phenolics and antioxidant activity, it is possible to note that the results are proportionally to the used amount of beetroot juice. As the main reason for using beetroot juice was to obtain a fermented beverage with high antioxidant activity, the beverages, NW 1:3 and CW 1:3, showed the higher total phenolic content and DPPH inhibition (Figs. 3 and 4). The antioxidant activity from beetroot juice allowed the improvement of the functional potential of the beverages already containing the probiotic yeast. The antioxidant potential of beetroot juice has been widely demonstrated in several studies. Works such as Wootton-Beard and Ryan (2011) reported a rate of DPPH inhibition up to $100 \%$ showing that beet juice has higher values than tomato juice and carrot juice. The antioxidant activity of beets comes mainly from compounds such as betalains (Pitalua et al.

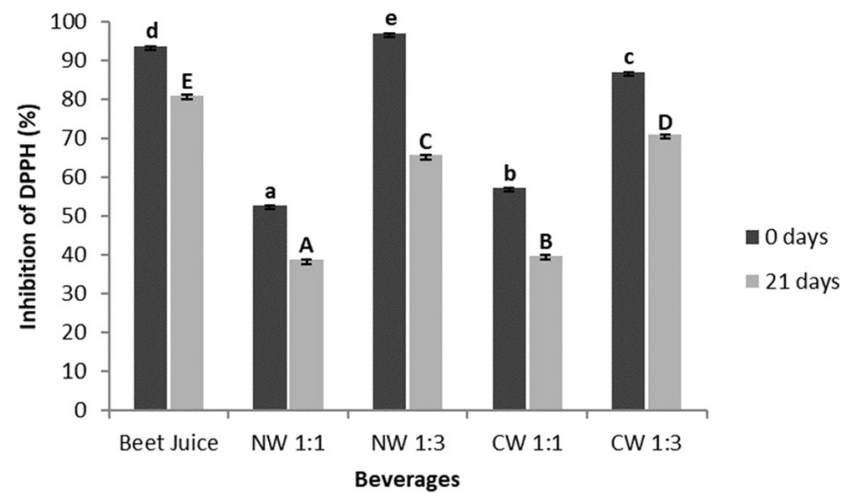

Fig. 4 Antioxidant potential (DPPH) of beverages at 0 and 21 days of storage under refrigeration at $4{ }^{\circ} \mathrm{C}$. NW $1: 1$, non-concentrated fermented cheese whey added to beetroot juice in a ratio of 1:1 (v:v); NW 1:3 (v:v), non-concentrated fermented cheese whey added to beetroot juice in the ratio of $1: 3(\mathrm{v}: \mathrm{v})$; CW 1:1, concentrated fermented cheese whey added to beetroot juice in the ratio of $1: 1(\mathrm{v}: \mathrm{v})$; CW 1:3, concentrated fermented cheese whey added to beetroot juice in the ratio of 1:3 (v:v). Different capital letters indicate statistical difference (Scott-Knott test $p<0.05$ ) between the beverages at 21 days of storage. Different lowercase letters indicate statistical difference (Scott-Knott test $p<0.05$ ) between the beverages at 0 days of storage 
2010) and beets are also rich in phenolic acids such as 4hydroxybenzoic acid, cinnamic acid, vanillic acid, chlorogenic acid, ferulic acid and caffeic acid, and gallic acid (Ravichandran et al. 2012; Wruss et al. 2015).

Beetroot is a source of antioxidants and many other healthpromoting components, such as folic acid, iron, magnesium, selenium, potassium, calcium, zinc, phosphorus, biotin, niacin, and $\beta$-carotene, as well as vitamins $\mathrm{A}, \mathrm{B} 6$, and $\mathrm{C}$. The high antioxidant capacity of beetroot along with its other compounds of nutritional value makes beetroot juice a positive component to be added to the diet (Wootton-Beard and Ryan 2011). Cheese whey also has advantageous nutritional properties such as proteins with a high content of essential amino acids, especially branched-chain ones, high calcium content, and bioactive peptides (Haraguchi et al. 2006). Besides these beneficial characteristics of beetroot and cheese whey, the probiotic potential of

Table 5 Concentrations of volatile compounds $(\mu \mathrm{g} / \mathrm{L})$ in fermented cheese whey added to 3 parts of beetroot juice

\begin{tabular}{|c|c|c|c|c|}
\hline No. & Compound & Beverage CW 1:3 & Beverage NW 1:3 & Descriptors \\
\hline \multicolumn{5}{|c|}{ Esters and acetates } \\
\hline 1 & Ethyl butanoate & $3796.09 \pm 10.51$ & $3905.30 \pm 5.43$ & Fruity ${ }^{\mathrm{a}}$ p papaya, butter, sweetish, apple, perfumed \\
\hline 2 & Ethyl pentanoate & $10.45 \pm 0.24$ & $11.35 \pm 0.38$ & - \\
\hline 3 & Ethyl hexanoate & $2832.33 \pm 1.37$ & $2748.96 \pm 5.83$ & Fruity, green apple ${ }^{\mathrm{b}}$ \\
\hline 4 & Ethyl heptanoate & $68.95 \pm 3.68$ & $111.41 \pm 9.07$ & - \\
\hline 5 & Ethyl benzoate & $120.00 \pm 5.85$ & $279.67 \pm 1.30$ & - \\
\hline 6 & Ethyl octanoate & $24756.23 \pm 45.91$ & $23259.67 \pm 18.07$ & Apple $^{\mathrm{b}}$ \\
\hline 7 & Ethyl nonanoate & $150.51 \pm 2.30$ & $293.24 \pm 11.80$ & Fruity ${ }^{\mathrm{c}}$ \\
\hline 8 & Ethyl 9-decenoate & $5203.96 \pm 42.01$ & $5043.09 \pm 21.14$ & $\operatorname{Rose}^{\mathrm{d}}$ \\
\hline 9 & Ethyl decanoate & $12302.95 \pm 59.41$ & $12886.65 \pm 40.51$ & Fruity, grape ${ }^{\mathrm{d}}$, woody ${ }^{\mathrm{e}}$ \\
\hline 10 & Ethyl 9-hexadecenoate & $178.74 \pm 3.83$ & $77.17 \pm 5.08$ & - \\
\hline 11 & Ethyl dodecanoate & $1605.15 \pm 17.23$ & $2737.31 \pm 9.49$ & Fruity, sweet $^{\mathrm{d}}$ \\
\hline 12 & Ethyl 11-hexadecenoate & $177.30 \pm 2.64$ & $217.54 \pm 6.72$ & - \\
\hline 13 & Ethyl tetradecanoate & $501.26 \pm 9.57$ & $804.66 \pm 14.08$ & - \\
\hline 14 & Ethyl undecanoate & $30.59 \pm 7.67$ & $20.83 \pm 1.57$ & - \\
\hline 15 & Ethyl hexadecanoate & $745.33 \pm 28.49$ & $612.13 \pm 1.50$ & Fruity, apple, wine-like ${ }^{\mathrm{d}}$ \\
\hline 16 & Ethyl linoleate & $377.32 \pm 2.68$ & $142.59 \pm 16.48$ & - \\
\hline 17 & Ethyl Oleate & $465.48 \pm 1.47$ & $369.30 \pm 0.51$ & - \\
\hline 18 & Propyl butanoate & $16.26 \pm 2.35$ & $31.45 \pm 1.04$ & - \\
\hline 19 & 2-Methylpropyl butanoate & $79.99 \pm 0.58$ & $78.93 \pm 3.59$ & - \\
\hline 20 & Butyl butanoate & $371.00 \pm 1.66$ & nd & - \\
\hline 21 & 3-Methylbutyl butanoate & $2009.78 \pm 83.48$ & $1394.87 \pm 11.31$ & - \\
\hline 22 & 2-Methylbutyl butanoate & $494.57 \pm 8.19$ & $640.76 \pm 4.06$ & - \\
\hline 23 & 2-Methylpropyl hexanoate & $10.13 \pm 1.59$ & $19.86 \pm 0.97$ & - \\
\hline 24 & 3-Methylbutyl hexanoate & $271.12 \pm 1.57$ & $253.20 \pm 8.24$ & - \\
\hline 25 & 2-Methylpropyl octanoate & $185.93 \pm 3.79$ & nd & - \\
\hline 26 & Phenethyl propionate & $90.42 \pm 2.97$ & $75.10 \pm 1.49$ & - \\
\hline 27 & Phenylethyl butanoate & $1978.71 \pm 12.58$ & $224.68 \pm 22.07$ & - \\
\hline 28 & 3-Methylbutyl octanoate & $787.01 \pm 38.51$ & $465.54 \pm 53.43$ & Pineapple $^{c}$ \\
\hline 29 & 2-Methylbutyl octanoate & $153.18 \pm 4.39$ & $190.58 \pm 3.40$ & - \\
\hline 30 & Propyl decanoate & nd & $14.16 \pm 0.44$ & Floral, bitter $^{\mathrm{f}}$ \\
\hline 31 & 2-Methylpropyl decanoate & $27.91 \pm 0.84$ & $25.27 \pm 2.00$ & - \\
\hline 32 & 3-Methylbutyl decanoate & $100.27 \pm 5.92$ & $95.58 \pm 1.91$ & - \\
\hline 33 & 2-Methylbutyl decanoate & $34.78 \pm 2.48$ & $34.41 \pm 3.07$ & - \\
\hline 34 & Isoamyl acetate & $58.12 \pm 7.34$ & $112.27 \pm 19.57$ & Banana $^{g}$ \\
\hline 35 & 2-Methyl-1-butanol acetate & $16.82 \pm 0.92$ & $20.57 \pm 2.35$ & - \\
\hline 36 & 2-Phenylethyl acetate & $10902.47 \pm 25.94$ & $3214.85 \pm 7.80$ & Flowery $^{\mathrm{d}}$; rose $^{\mathrm{c}}$ \\
\hline \multicolumn{5}{|c|}{ Acids } \\
\hline 37 & Octanoic acid & $593.37 \pm 22.83$ & $570.93 \pm 4.46$ & Rancid, harsh ${ }^{\mathrm{g}}$; fatty acids, vegetable oil ${ }^{4}$ \\
\hline 38 & Decanoic acid & $923.01 \pm 4.75$ & $812.74 \pm 17.00$ & Fatty $^{\mathrm{g}}$; wax, tallow, rancid, soap ${ }^{\mathrm{b}}$ \\
\hline 39 & Dodecanoic acid & $50.34 \pm 1.49$ & $102.33 \pm 12.61$ & - \\
\hline 40 & Hexadecanoic acid & $24.59 \pm 2.68$ & $32.04 \pm 0.14$ & - \\
\hline 41 & Nonanal & $52.66 \pm 1.08$ & $57.20 \pm 2.49$ & Citrus-like, soapy $^{\mathrm{a}}$ \\
\hline 42 & Decanal & $43.88 \pm 0.82$ & $17.71 \pm 1.04$ & Orange $^{c}$ \\
\hline \multicolumn{5}{|c|}{ Alcohols } \\
\hline 43 & 3-Methyl-1-butanol and 2-Methyl-1butanol & $2430.95 \pm 29.07$ & $1599.12 \pm 28.56$ & Fruity, sweet ${ }^{\mathrm{a}}$ \\
\hline 44 & 2-Phenylethanol & $183.31 \pm 2.49$ & $269.96 \pm 4.90$ & Flowery, honey-like $^{\mathrm{a}}$ \\
\hline
\end{tabular}

nd, not detected; NW 1:3, non-concentrated fermented cheese whey added to beetroot juice in the ratio of 1:3 (v:v)

CW 1:3, concentrated fermented cheese whey added to beetroot juice in the ratio of $1: 3(\mathrm{v}: \mathrm{v})$

${ }^{\mathrm{a}}$ Czerny et al. (2008), ${ }^{\mathrm{b}}$ Meilgaard (1975), ${ }^{\mathrm{c}}$ Soares et al. (2015), ${ }^{\mathrm{d}}$ Costa et al. (2018), ${ }^{\mathrm{e}}$ Ledauphin et al. (2003), ${ }^{\mathrm{f}}$ Alves et al. (2015), ${ }^{\mathrm{g}}$ Siebert et al. (2005) 
yeasts makes the produced beverages promising in the context of functional foods.

\section{Volatile compounds}

Based on the phenolic content and antioxidant activity, the beverages added to 3 parts of beetroot juice were submitted to HS SPME GC-MS analysis. Forty-four volatile compounds were identified in the produced beverages (Table 5). For most compounds, the profile and concentrations found were similar in the two beverages (Fig. 5). The principal component analysis shows that the first two components (PC1 and PC2) accounted for 100\% of the total variance. Only 2-phenylethyl acetate (compound no. 36) allowed a slight differentiation between the beverages.

The ester and acetate group presented the highest number of compounds (Table 5). The highest production of esters and acetates agrees with the expected, considering the use of $K$. lactis, a known yeast for its efficiency for the production of these compounds. Ethyl octanoate was the most abundant compounds measured in the beverages CW 1:3 and NW 1:3 in concentrations of $24756.23 \mu \mathrm{g} / \mathrm{L}$ and $23259.67 \mu \mathrm{g} / \mathrm{L}$, respectively (Table 5). The second highest concentration was found for ethyl decanoate with values of $12302.95 \mu \mathrm{g} / \mathrm{L}$ and $12886.65 \mu \mathrm{g} / \mathrm{L}$ in the beverages CW 1:3 and NW 1:3, respectively (Table 5). Ethyl octanoate and ethyl decanoate are associated with descriptors such as "sweet, apple, and fruity" (Meilgaard 1975). Other esters and acetates were also measured in high concentration (Table 5). Most of them were above the odor thresholds commonly reported. The great diversity of esters and acetates and their high concentrations were a positive point in the fermentation of whey by $K$. lactis B9. According to Zheng et al. (2018), in cheese, esters are desirable volatile compounds because they have "fruity" and high volatility. This may help to mask the undesirable flavors, for example, of the acids and other compounds.

The group of acids was composed only by 4 compounds, octanoic, decanoic, dodecanoic, and hexadecenoic acids (Table 5). Decanoic acid was found in concentrations of $923.01 \mu \mathrm{g} / \mathrm{L}$ and $812.74 \mu \mathrm{g} / \mathrm{L}$ in beverages CW 1:3 and NW 1:3, respectively (Table 5). This compound has aroma descriptors "wax, tallow, rancid, soap" (Meilgaard 1975).

The least diverse groups were those of the alcohols and aldehydes (Table 5). 3-Methyl-1-butanol, 2-methyl-1butanol, and 2phenylethanol were the found alcohols. 2-Phenethylethanol is associated with descriptors such as "flowery and honey-like" (Czerny et al. 2008). The isoamyl alcohols (3-methyl-1-butanol and 2-methyl-1butanol) are important for the aroma of many fermented products since they present descriptors such as "fruity and sweet." Only two aldehydes were found in the beverages CW 1:3 and NW 1:3 (Table 5). Nonanal was the most abundant aldehyde being measured in concentrations of $52.66 \mu \mathrm{g} / \mathrm{L}$ and $57.20 \mu \mathrm{g} / \mathrm{L}$ respectively in the beverages CW $1: 3$ and NW 1:3 (Table 5). This compound is commonly associated with aroma descriptors "Citrus-like, soapy" (Czerny et al. 2008).

In general, it can be noted that the profile of volatile compounds was characterized by compounds from the fermentation. The addition of beetroot juice after the fermentation of the cheese whey did not strongly affect the composition of aromatic volatiles.

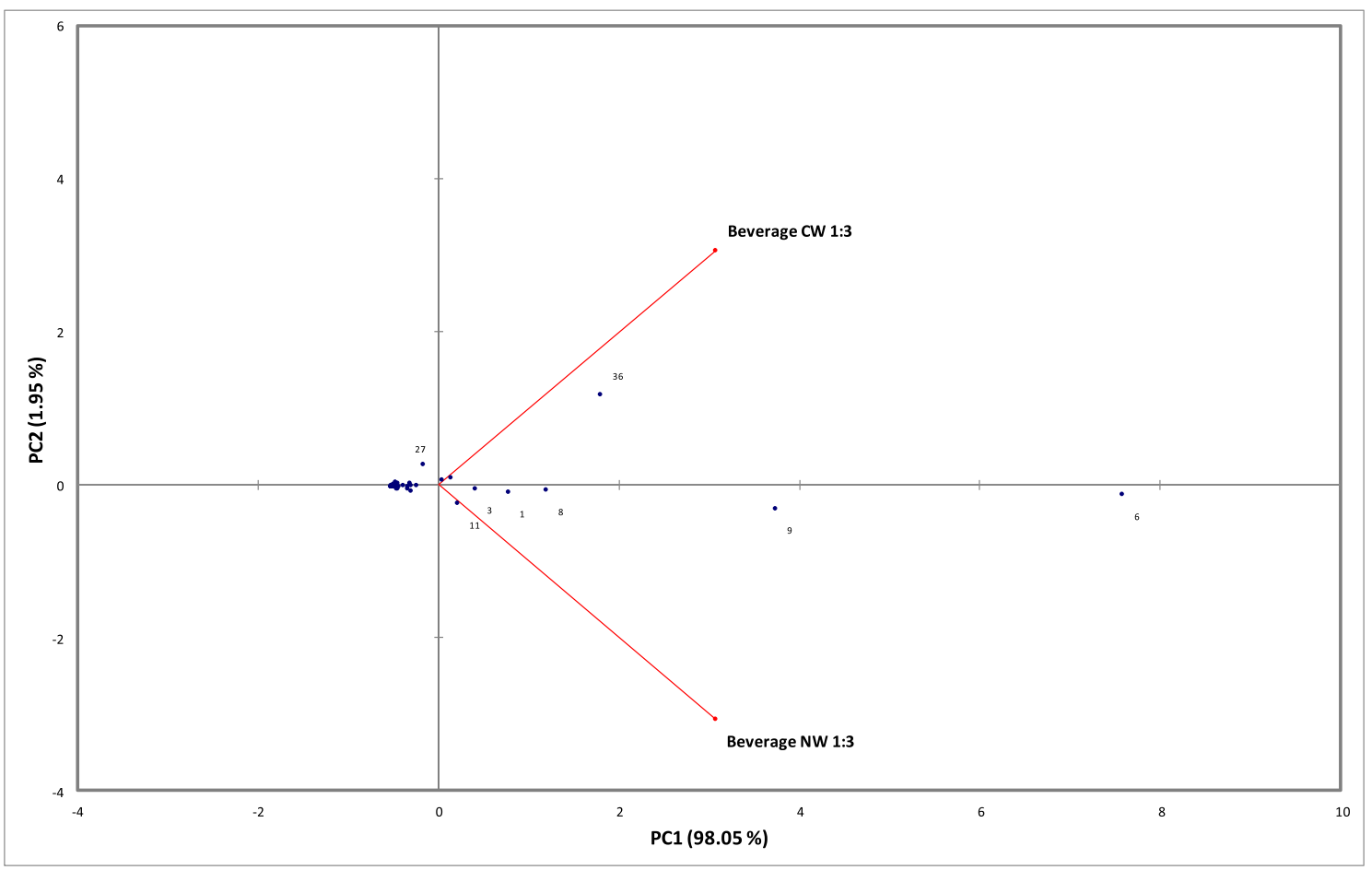

Fig. 5 Principal component analysis of volatile compounds 


\section{Conclusions}

Due to its survival performance during passage through the simulated gastrointestinal tract, indicative of adhesion to the intestinal epithelium, $\beta$-galactosidase activity, production of shortchain fatty, and survival during 21 days of the beverage storage under refrigeration, $K$. lactis B9 is a promising strain for the manufacture of cheese whey-based functional beverages. Another point to be highlighted is the probable innocuity of the used strain. As the yeast was isolated from a cheese made with raw milk, it is already consumed alive in this product. Regarding the produced beverages, they stand out by their antioxidant properties and for being lactose-free without addition of commercial $\beta$-galactosidase, which is advantageous from both economic and functional points of view. Considering the fact that both the concentrated and the diluted cheese whey resulted in the generation of fermented beverages with many esters and acetates (whose aroma descriptors are "fruity, sweet, floral, etc."), the use of the diluted cheese whey is an interesting alternative to the concentrated one. The production of the latter implies a relatively highcost process in the industry.

Funding information This study was financially supported by the Coordenação de Aperfeiçoamento de Pessoal de Nível Superior-Brasil (CAPES) - Finance Code 001, Conselho Nacional de Desenvolvimento Científico e Tecnológico do Brasil (CNPq), and Fundação de Amparo à Pesquisa de MG (FAPEMIG).

\section{Compliance with ethical standards}

Conflict of interest The authors declare that they have no conflict of interest.

Research involving human participants and/or animals This study did not involve human participants or animals.

Informed consent The authors mutually agree with the submission of the manuscript to Annals of Microbiology.

\section{References}

Aloglu HS, Ozer ED, Oner Z (2016) Assimilation of cholesterol and probiotic characterization of yeast strains isolated from raw milk and fermented foods. Int J Dairy Technol 69:63-70

Alves Z, Melo A, Figueiredo AR, Coimbra MA, Gomes AC, Rocha SM (2015) Exploring the Saccharomyces cerevisiae volatile metabolome: indigenous versus commercial strains. PLoS ONE 10(11): e0143641

Amorim JC, Piccoli RH, Duarte WF (2018) Probiotic potential of yeasts isolated from pineapple and their use in the elaboration of potentially functional fermented beverages. Food Res Int 107:518-527

Andrade RP, Melo CN, Genisheva Z, Schwan RF, Duarte WF (2017) Yeasts from Canastra cheese production process: isolation and evaluation of their potential for cheese whey fermentation. Food Res Int 91:72-79

Beards E, Tuohy K, Gibson G (2010) Bacterial, SCFA and gas profiles of a range of food ingredients following in vitro fermentation by human colonic microbiota. Anaerobe 16:420-425
Cardoso VM, Borelli BM, Lara CA, Soares MA, Pataro C, Bodevan EC, Rosa CA (2015) The influence of seasons and ripening time on yeast communities of a traditional Brazilian cheese. Food Res Int 69:331-340

Ceugniez A, Drider D, Jacques P, Coucheney F (2015) Yeast diversity in a traditional French cheese "Tommed'orchies" reveals infrequent and frequent species with associated benefits. Food Microbiol 52: $177-184$

Ceugniez A, Coucheney F, Jacques P, Daube G, Delcenserie V, Drider D (2017) Anti-Salmonella activity and probiotic trends of Kluyveromyces marxianus S-2-05 and Kluyveromyces lactis S-305 isolated from a French cheese, Tommed'Orchies. Res Microbiol 168:575-582

Chen LS, Ma Y, Maubois JL, Chen LJ, Liu QH, Guo JP (2010a) Identification of yeasts from raw milk and selection for some specific antioxidant properties. Int J Dairy Technol 63:47-54

Chen LS, Ma Y, Maubois JL, He SH, Chen LJ, Li HM (2010b) Screening for the potential probiotic yeast strains from raw milk to assimilate cholesterol. Dairy Sci Technol 90:537-548

Chen G, Xie M, Wan P, Chen D, Ye H, Chen L, Liu Z (2018) Digestion under saliva, simulated gastric and small intestinal conditions and fermentation in vitro by human intestinal microbiota of polysaccharides from Fuzhuan brick tea. Food Chem 244:331-339

Costa MGM, Fonteles TV, De Jesus ALT, Rodrigues S (2013) Sonicated pineapple juice as substrate for $L$. casei cultivation for probiotic beverage development: process optimization and product stability. Food Chem 139:261-266

Costa GP, Nicolli KP, Welke JE, Manfroi V, Zini CA (2018) Volatile profile of sparkling wines produced with the addition of mannoproteins or lees before second fermentation performed with free and immobilized yeasts. J Braz Chem Soc 29:1866-1875

Cummings JH, Macfarlane GT (2002) Gastrointestinal effects of prebiotics. Br J Nutr 87:145-151

Cummings J, Pomare EW, Branch WJ, Naylor CP, Macfarlane GT (1987) Short-chain fatty acids in human large intestine, portal, hepatic and venous blood. Gut 28:1221-1227

Czerny M, Christbauer M, Christbauer M, Fischer A, Granvogl M, Hammer M, Hartl C, Hernandez NM, Schieberle P (2008) Re-investigation on odour thresholds of key food aroma compounds and development of an aroma language based on odour qualities of defined aqueous odorant solutions. Eur Food Res Technol 228:265-273

Di T, Chen G, Sun Y, Ou S, Zeng X, Ye H (2018) In vitro digestion by saliva, simulated gastric and small intestinal juices and fermentation by human fecal microbiota of sulfated polysaccharides from Gracilaria rubra. J Funct Foods 40:18-27

Diosma G, Romanin DE, Rey-Burusco M, Londero A, Garrote GL (2014) Yeasts from kefir grains: isolation, identification, and probiotic characterization. World J Microbiol Biotechnol 30:43-53

Duarte WF, Dias DR, Oliveira JM, Teixeira JA, de Almeida JBS, Schwan RF (2010) Raspberry (Rubus idaeus L.) wine: yeast selection, sensory evaluation and instrumental analysis of volatile and other compounds. Food Res Int 43:2303-2314

Escudero-López B, Cerrillo I, Gil-Izquierdo Á, Hornero-Méndez D, HerreroMartín G, Berná G, Fernández-Pachón MS (2016) Effect of thermal processing on the profile of bioactive compounds and antioxidant capacity of fermented orange juice. Int J Food Sci Nutr 67:779-788

Fadda ME, Mossa V, Deplano M, Pisano MB, Cosentino S (2017) In vitro screening of Kluyveromyces strains isolated from Fiore Sardo cheese for potential use as probiotics. LWT-Food Sci Technol 75:100-106

FAO and WHO (2002) Guidelines for the evaluation of probiotics in food. [internet document] URL http://www.fao.org/es/ESN/Probio/ probio.htm/. Accessed 10/11/2013.

Gänzle MG, Haase G, Jelen P (2008) Lactose: crystallization, hydrolysis and value-added derivatives. Int Dairy J 18:685-694

Gibson GR, Probert HM, Van Loo J, Rastall RA, Roberfroid MB (2004) Dietary modulation of the human colonic microbiota: updating the concept of prebiotics. Nutr Res Rev 17:259-275 
Guyton AC, Hall JE (2011) Tratado de Fisiologia Médica. Elsevier, Rio de Janeiro

Haraguchi FK, Abreu WC, Paula HD (2006) Proteínas do soro do leite: composição, propriedades nutricionais, aplicações no esporte e benefícios para a saúde humana. Rev Nutr 19:479-488

Hatoum R, Labrie S, Fliss I (2012) Antimicrobial and probiotic properties of yeasts: from fundamental to novel applications. Front Microbiol 3:1-12

Kiefer I, Prock P, Lawrence C, Wise J, Bieger W, Bayer P, Rieder A (2004) Supplementation with mixed fruit and vegetable juice concentrates increased serum antioxidants and folate in healthy adults. J Am Coll Nutr 23:205-211

Kos B, Susković J, Vuković S, Simpraga M, Frece J, Matosi S (2003) Adhesion and aggregation ability of probiotic strain Lactobacillus acidophilus M92. J Appl Microbiol 94:981-987

Kumura H, Tanoue Y, Tsukahara M, Tanaka T, Shimazaki K (2004) Screening of dairy yeast strains for probiotic applications. J Dairy Sci 87:4050-4056

Ledauphin J, Guichard H, Saint-Clair JF, Picoche B, Barillier D (2003) Chemical and sensorial aroma characterization of freshly distilled calvados. 2. Identification of volatile compounds and key odorants. J Agric Food Chem 51:433-442

Maccaferri S, Klinder A, Brigidi P, Cavina P, Costabile A (2012) Potential probiotic Kluyveromyces marxianus B0399 modulates the immune response in Caco- 2 cells and peripheral blood mononuclear cells and impacts the human gut microbiota in an in vitro colonic model system. Appl Environ Microbiol 78:956-964

Mäkeläinen HS, Mäkivuokko HA, Salminen SJ, Rautonen NE, Ouwehand AC (2007) The effects of polydextrose and xylitol on microbial community and activity in a 4-stage colon simulator. $\mathrm{J}$ Food Sci 72:M153-M159

Meilgaard MC (1975) Flavor chemistry of beer: Part II: flavor and threshold of 239 aroma volatiles. MBAA Techn Q 12:151-168

Park SC, Hwang MH, Kim YH, Kim JC, Song JC, Lee KW, Kim TW (2006) Comparison of $\mathrm{pH}$ and bile resistance of Lactobacillus acidophilus strains isolated from rat, pig, chicken, and human sources. World J Microbiol Biotechnol 22:35-37

Patel S (2015) Functional food relevance of whey protein: a review of recent findings and scopes ahead. J Funct Foods 19:308-319

Pitalua E, Jimenez M, Vernon-Carter EJ, Beristain CI (2010) Antioxidative activity of microcapsules with beetroot juice using gum Arabic as wall material. Food Bioprod Process 88:253-258

Rajkowska K, Kunicka-Styczynsk A (2010) Probiotic properties of yeasts isolated from chicken feces and kefirs. Pol J Microbiol 59:257-263
Ravichandran K, Ahmed AR, Knorr D, Smetanska I (2012) The effect of different processing methods on phenolic acid content and antioxidant activity of red beet. Food Res Int 48:16-20

Richards LB, Li M, Van Esch BCAM, Garssen J, Folkerts G (2016) The effects of short-chain fatty acids on the cardiovascular system. Pharma Nutr 49:68-111

Saber A, Alipour B, Faghfoori Z, Khosroushahi AY (2017) Secretion metabolites of dairy Kluyveromyces marxianus AS41 isolated as probiotic, induces apoptosis in different human cancer cell lines and exhibit anti-pathogenic effects. J Funct Foods 34:408-421

Siebert TE, Smyth HE, Capone DL, Neuwöhoner C, Pardon KH, Skouroumounis GK, Herderich MJ, Sefton MA, Pollnitz AP (2005) Stable isotope dilution analysis of wine fermentation products by HS-SPME-GC-MS. Anal Bioanal Chem 381:937-947

Soares RD, Welke JE, Nicolli, KP, Zanus M (2015) Monitoring the evolution of volatile compounds using gas chromatography during the stages of production of Moscatel sparkling wine. Food Chem 183: 291-304

Song C, Liu GL, Xu JL, Chi ZM (2010) Purification and characterization of extracellular $\beta$-galactosidase from the psychrotolerant yeast Guehomyces pullulans 17-1 isolated from sea sediment in Antarctica. Process Biochem 45:954-960

Spohner SC, Schaum V, Quitmann H, Czermak P (2016) Kluyveromyces lactis: an emerging tool in biotechnology. J Biotechnol 222:104-116

Syal P, Vohra A (2013) Probiotic potential of yeasts isolated from traditional Indian fermented foods. Int J Microbiol Res 5:390-398

Wootton-Beard PC, Ryan L (2011) A beetroot juice shot is a significant and convenient source of bioaccessible antioxidants. J Funct Foods 3:329-334

Wruss J, Waldenberger G, Huemer S, Uygun P, Lanzerstorfer P, Müller U, Weghuber J (2015) Compositional characteristics of commercial beetroot products and beetroot juice prepared from seven beetroot varieties grown in Upper Austria. J Food Compos Anal 42:46-55

Zheng X, Li K, Shi X, Ni Y, Li B, Zhuge B (2018) Potential characterization of yeasts isolated from Kazak artisanal cheese to produce flavoring compounds. Microbiologyopen 7:e00533

Publisher's note Springer Nature remains neutral with regard to jurisdictional claims in published maps and institutional affiliations. 